\title{
COMPARATIVE STUDIES ON THE BIOLOGICAL ASPECTS OF TRICHOGRAMMA EVANESCENS AND TRICHOGRAMMA BRASSICAE REARED ON UV- IRRADIATED EGGS OF FACTITIOUS HOSTS
}

\author{
EL-NAGGAR, M. E. ${ }^{1}$ S .GAFFAR. ${ }^{2} *$ and W. Z. A. ${ }^{3}$ MIKHAIL \\ 1. Agricultural Research Center, ARC, Giza, Egypt. \\ 2. Central Laboratory of Organic Agriculture, ARC, Giza, Egypt. \\ 3. Dep. Natural Resources, Inst. African Research \&studies, Cairo Univ., 12613 Giza, \\ Egypt. \\ *Corresponding author. Email: saad_bio_organic@yahoo.com
}

(Manuscript received 13 February 2012)

\begin{abstract}
Ultraviolet (UV) was used to sterilize the eggs of Angoumois Grain Moth (AGM), Sitotroga cerealella (Olivier), the Mediterranean Flour Moth (MFM), Ephestia and kuehniella Zeller to stop the embryonic development inside the eggs to be favorable for parasitism for longer time. This system was developed to prolong the storage capability of the eggs used for rearing the bioagents. Results indicated significant difference between the fecundity of Trichogramma evanescens and T. brassicae at $25^{\circ} \mathrm{C}$ (L.S.D at $5 \% 10.18$ ) reared on AGM and MFM. The data indicated, the highest number of black eggs reached 63.5 and 38.1 when in case of $T$. brassicae and $T$. evanescens on eggs of MFM with UV, respectively. While it reached 31.9 and 16.4 for the same species on the eggs of AGM with UV, respectively.

Key Words: Ultraviolet, embryonic development, cannibalism, storage, fecundity.
\end{abstract}

\section{INTRODUCTION}

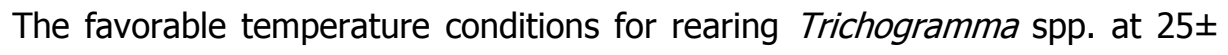
$1^{\circ} \mathrm{C}, 70 \pm 5 \% \mathrm{RH}$, was recorded by (Bigler, 1994 and Gaffar, 2006). The first author who exposed Corcyra cephalonica to UV radiation conducted by (Preniere, 1965) to kill the embryos whereas (Zhang et. al. 1991) used the same radiation to sterilize the eggs to be used for rearing $T$. ostriniae. While, Voegele et. al. 1975 studied the conditions of E. keuhniella eggs by irrigated it for 4 hours and held at $4{ }^{\circ} \mathrm{C}$ four days in $T$. evanescens and T. brasiliensis in case of rearing program. The present study was conducted to describe the system of UV radiation and to evaluate the exposure of different alternative hosts eggs ( MFM \& AGM ) for UV radiation for using in mass rearing program. 


\section{MATERIALS AND METHODS}

\section{UV Cabinet}

The ultraviolet cabinet was composed of four interlocked compartments. The internal one is $30 \mathrm{~cm}$ long, $30 \mathrm{~cm}$ wide and $60 \mathrm{~cm}$ depth. The internal chamber was covered by stainless and contains stainless tray $29 \times 29 \times 1.5 \mathrm{~cm}$. the distance from tray to starting the UV lamp is $23 \mathrm{~cm}$ and, each one contains timer to define the time of exposure and turn off automatically after finish the exposure time. Specifications of the lamp, Model VL-115 G- Tube (Watt) 1X15 W -Wave length (nm) 254- intensity ( $\mu$ w/cm) 31 was fixed (Fig. 1).

\section{Techniques of rearing factitious hosts}

The methodology used for rearing $S$. cerealella was mentioned by (Hassan, 1981 \& 1994) was followed the improvement methods for rearing E. keuhniella was described by (El-Arnaouty, 2001 and Gaffar, 2006), while mass rearing of the parasitoids Trichogramma spp. was previously mentioned by (Hoffman et. al., 1995 and Abd El-Hafez, 2001). E. keuhniella Zeller and S. cerealella (Olivier) were used as alternative hosts for $T$. evanescens and $T$. brassicae colony maintainance. The colony was established with eggs provided by "the Central Laboratory for mass rearing of Trichogramma parasitoid at El-Fayoum governorate".

\section{Parasite rearing}

For efficient mass rearing of $T$. evanescens or $T$. brassicae, host egg sheets (2000 egg) were exposed to adult (100 adults) into 0.4 liter glass jar provided with 10 $\%$ sucrose solution for nutrition and covered with cloth-wrapped cotton, as described by (Abd El-Hafez, 2001). These colony was established with parasitoids provided by Central Laboratory for mass rearing of Trichogramma parasitoid at El-Fayoum governorate at $25 \pm 1{ }^{\circ} \mathrm{C}, 70 \pm 5 \% \mathrm{RH}$ and a $16: 8 \mathrm{~h}$ (L:D) photoperiod.

\section{Experimental Protocol}

The experiment was consisted 8 treatments confined in the same time, each treatment was involved 30 replicates and 30 newly emerged females from the strain reared on $S$. cerealella (less than $24 \mathrm{~h}$ old) from each species. They were transferred singly to glass tubes provided with a drop of $10 \%$ honey solution on the inner wall as feeding source for the parasitoid females. After that calculate the no. of black eggs for each species (2 treatments) on E. keuhniella with UV \& without UV irradiated and (2 treatments) on $S$. cerealella with UV \& without UV irradiate was calculated.

\section{Data analysis}

The count of black eggs was submitted to ANOVA using SAS program (1988). 


\section{RESULTS AND DISCUSSION}

1- Effect of eggs exposure of S. cerealella and E. keuhniella to UV radiation on some biological aspects of T. brassicae and T. evanescens which reared on eggs of S. cerealella at $25^{\circ} \mathrm{C}$.

\subsection{Fecundity of $T$. brassicae}

When exposed $T$. brassicae on eggs of $E$. keuhniella irradiated and unirradiated UV irradiation or not at $25^{\circ} \mathrm{C}$ resulted from colony of $T$. brassicae reared on eggs of $S$. cerealella gave high mean number of black eggs of 63.47 and 60.37 , respectively. While, they gave less mean numbers of black eggs when the colony of $T$. brassicae exposed on eggs of $S$. cerealella irradiated and unirradiated with UV radiation at $25^{\circ} \mathrm{C}$ were 31.90 and 21.03 , respectively (Fig. 2). Also, results showed that rearing of $T$. brassicae on eggs of $E$. keuhniella exposed or did not expose to UV radiation at $25^{\circ} \mathrm{C}$ gave high parasitism ratio of $65.58 \% \pm 15.62$ and $64.39 \% \pm 16.02$, respectively. While, less parasitism ratio\% was obtained when the colony of $T$. brassicae exposed on eggs of $S$. cerealella exposed and did not expose to UV radiation at $25^{\circ} \mathrm{C}$ where the corresponding values of parasitism were $41.67 \% \pm 11.60$ and $25.94 \% \pm 10.07$, respectively (Fig. 3). On the other hand, data revealed that rearing of $T$. brassicae on eggs of $E$. keuhniella exposed and did not expose to UV radiation or not at $25^{\circ} \mathrm{C}$ gave mortality rate of 30 and $33.33 \%$, respectively. While rearing on eggs of $S$. cerealella exposed and did not expose to UV radiation at $25^{\circ} \mathrm{C}$ gave 96.67 and $90.00 \%$ mortality, respectively (Fig. 4).

Statistical analysis showed significant differences between rearing on different hosts irradiated with UV and other without exposure to UV on the fecundity of $T$. brassicae at $25^{\circ} \mathrm{C}$ (L.S.D at $5 \% 10.49$ ).

The obtained results are in agreement with those obtained by Preniere, 1965 who exposed Corcyra cephaalonica eggs for $15 \mathrm{~min}$. to UV radiation that killed the embryos, while the treated eggs were continued suitable and acceptable for application of the egg parasitoids, T. autralicum Girault.

\subsection{Fecundity of $T$. evanescens}

Exposure of $T$. evanescens on eggs of $E$. keuhniella exposed and did not expose to UV radiation or not at $25^{\circ} \mathrm{C}$ resulted from a colony of $T$. evanescens reared on eggs of $S$. cerealella gave high mean number of black eggs of 38.10 and 59.77, respectively. While, the procedure gave less mean number of black eggs when the colony of $T$. evanescens introduced to eggs of $S$. cerealella exposed and without exposure to UV radiation at $25^{\circ} \mathrm{C}$, where the numbers of black eggs were 16.40 and 24.30, respectively (Fig. 5). Also, results showed that rearing of $T$. evanescens on 
eggs of E. keuhniella exposed and without exposure to UV radiation at $25^{\circ} \mathrm{C}$ gave high parasitism ratio of $47.96 \% \pm 16.49$ and $61.59 \% \pm 12.48$, respectively. While, less of parasitism ratio was occurred when the colony of $T$. evanescens introduced to on eggs of $S$. cerealella exposed and without exposure to UV radiation or not at $25^{\circ} \mathrm{C}$ where the correspondent parasitism ratio were $25.33 \% \pm 13.85$ and $26.30 \% \pm 7.19$, respectively (Fig. 6). On the other hand, data revealed that rearing of $T$. evanescens on eggs of E. keuhniella exposed or without exposure to UV radiation at $25^{\circ} \mathrm{C}$ gave mortality \% 33.33 and $13.33 \%$ mortality, respectively. While rearing carried out on eggs of $S$. cerealella exposed and without exposure to UV radiation at $25^{\circ} \mathrm{C}$ gave 80 and $30 \%$ mortality, respectively (Fig. 7).

Statistical analysis showed significant differences between rearing on different hosts radiated with UV and other without exposure to UV on fecundity of $T$. evanescens at $25^{\circ} \mathrm{C}$.

Voegele et. al. (1975), studied the conditions of eggs of E. kuehniella by cold and UV radiation in $T$. evanescens and $T$. brasiliensis rearing program. It was detected after these insects were reared through 6 successive generations on eggs irradiated for 4 hours and held at $4^{\circ} \mathrm{C}$ for days. The fertility of $T$. brasiliensis was even increased by this treatment.

2- $\quad$ Comparison between exposure and non exposure eggs of $S$. cerealella to UV radiation on fecundity for $T$. brassicae and $T$. evanescens at $25^{\circ} \mathrm{C}$.

Data illustrated in (Fig. 8) showed significant differences between rearing on different hosts irradiated with UV and other without exposure to UV on fecundity of $T$. brassicae and T. evanescens at $25^{\circ} \mathrm{C}$ (L.S.D at $5 \%$ 10.18).

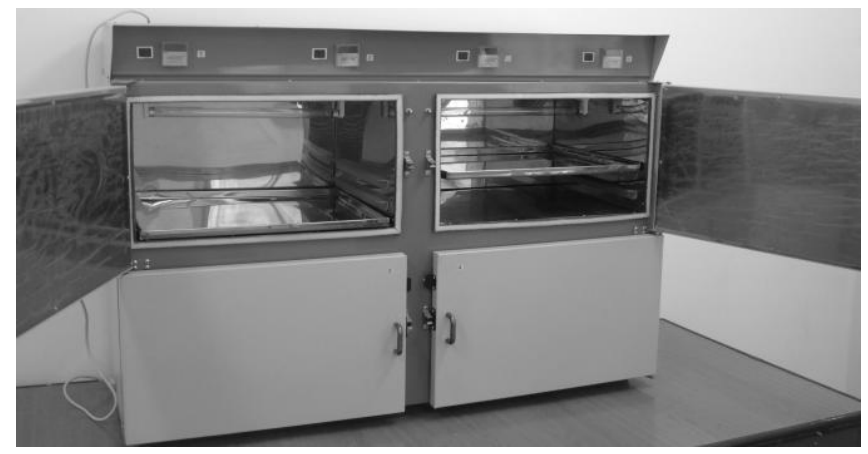

Fig. 1. UV Cabinet 


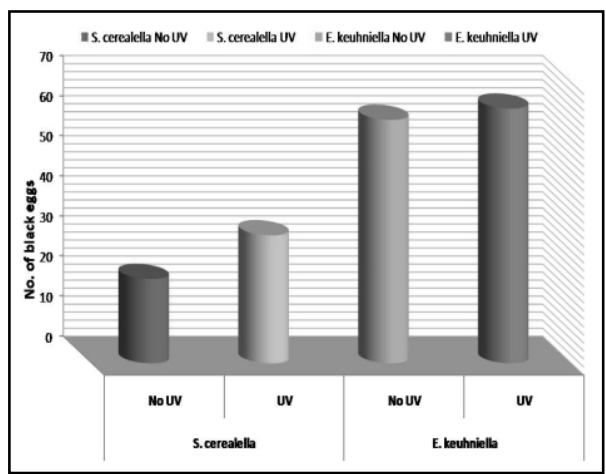

Fig (2): Effect of exposure eggs of different alternative hosts to UV radiation on fecundity of Trichogramma brassicae which reared on Eggs of Sitotroga cerealella at $25^{\circ} \mathrm{C}$

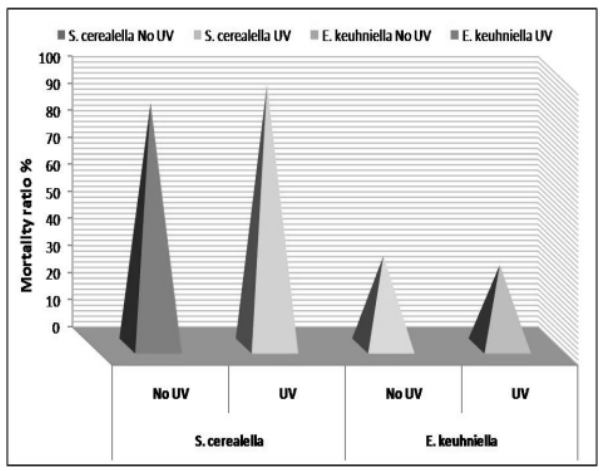

Fig (4): Effect of exposure eggs of different alternative hosts to UV radiation on mortality ratio \% of Trichogramma brassicae which reared on eggs of Sitotroga cerealella at $25^{\circ} \mathrm{C}$

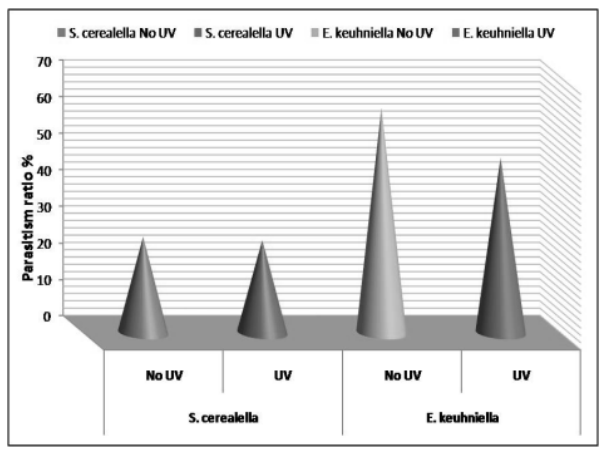

Fig (6): Effect of exposure eggs of different alternative hosts to UV radiation on parasitism ratio \% of Trichogramma evanescenswhich reared on eggs of Sitotroga cerealella at $25^{\circ} \mathrm{C}$

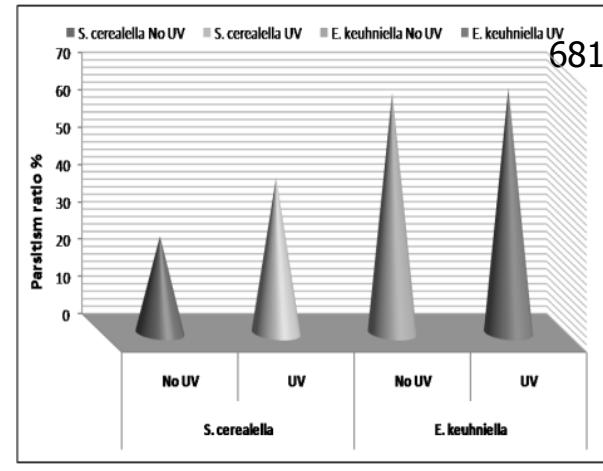

Fig (3): Effect of exposure eggs of different alternative hosts to UV radiation on Parasitism ratio \% of Trichogramma brassicae which reared on eggs of Sitotroga cerealella at $25^{\circ} \mathrm{C}$

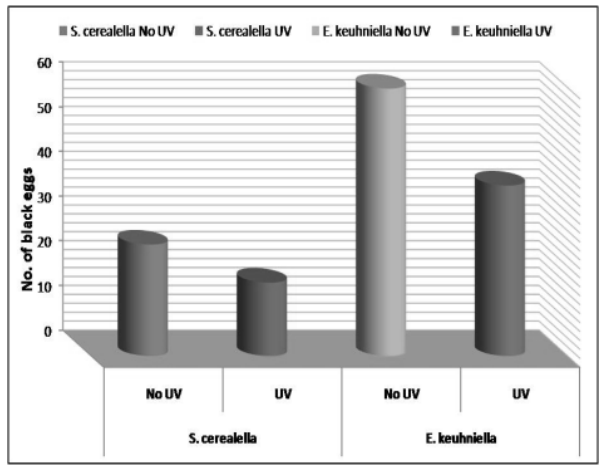

Fig (5): Effect of exposure eges of different alternative hosts to UV radiation on fecundity of Trichogramma evanescens which reared on eggs of Sitotroga cerealella at $25^{\circ} \mathrm{C}$

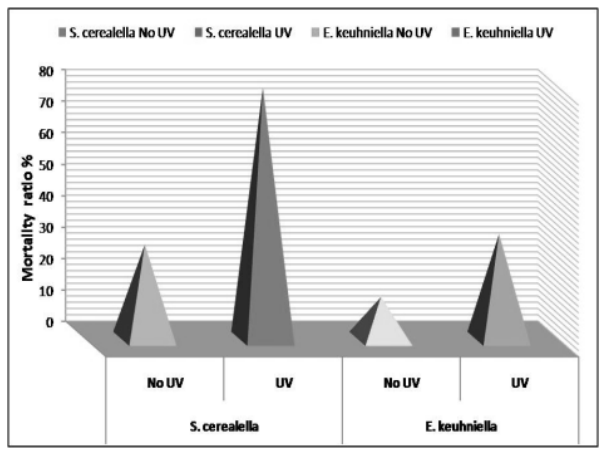

Fig (7): Effect of exposure eggs of different alternative hosts to UV radiation on mortality ratio \% of Trichogramma evanescens which reared on eggs of Sitotroga cerealella at $25^{\circ} \mathrm{C}$ 


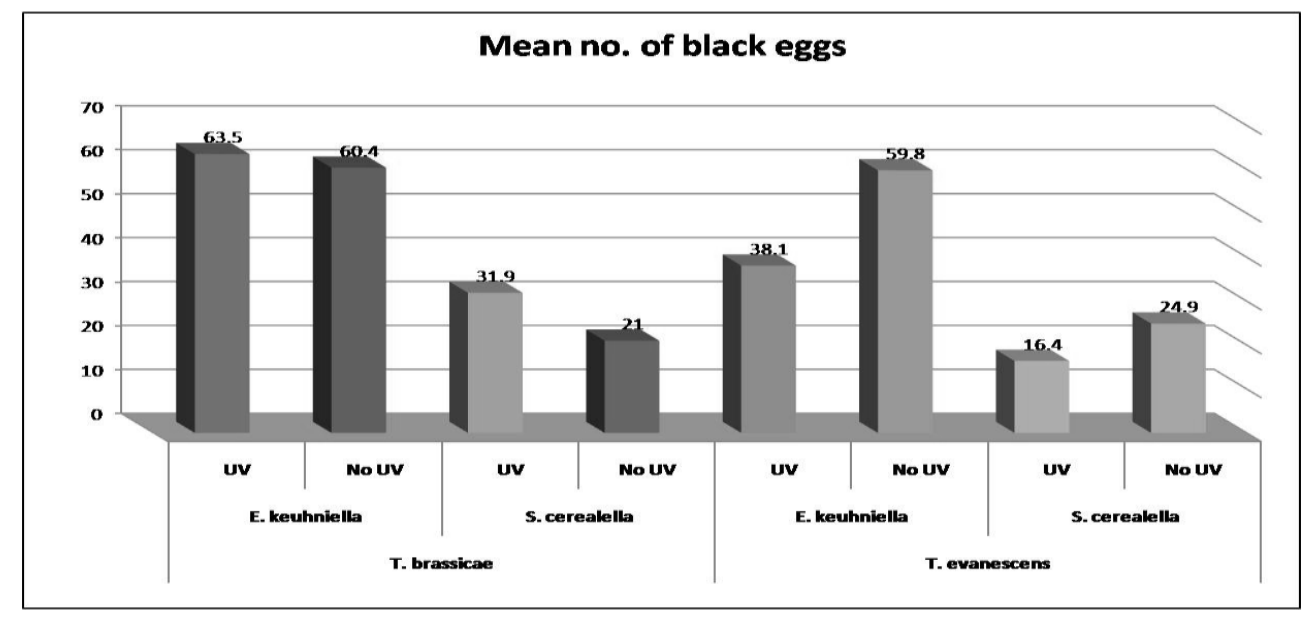

Fig. 8. Comparison between exposure and non exposure eggs of S. cerealella to UV radiation on fecundity for $T$. brassicae and T. evanescens at $25{ }^{\circ} \mathrm{C}$.

\section{REFERENCES}

1. Abd El-Hafez, Alia. 2001. The effect of egg size of the pink bollworm and some lepidopterous insects on the quality attributes of Trichogramma evanescens and Trichogramma bactrae. Egyptian Journal of Biological Pest Control, 11 (1): 1-13.

2. Bigler, F. 1994. The rearing of Trichogramma. In: Ochieng-Odero, J. P. R. (ed.), Techniques of Insect Rearing for the Development of Integrated Pest and Vector Management Strategies. ICIPE Science Press, Nairobi, Kenya, 315-329.

3. El-Arnaouty, S. A. 2001. Technical improvements in mass rearing of Ephestia kuehniella Zeller (Lep.: Pyralidae) as a substitution prey for a cost effective production of Crysoperla carnea Steph. Integrated Pest Management, Proc. Of the $1^{\text {st }}$ Congress, Cairo Univ., Fac. Agric., 22-23 April, Part I, 42-52.

4. Gaffar, S. 2006. Some factors affecting parasites on potential of some Trichogramma parasitoid species under mass rearing conditions in Egypt and Tunisia. M. Sc. Thesis, Institute of African Research and Studies. Cairo Univ., 145 pp.

5. Hassan, S. A. 1981. Mass production and utilization of Trichogramma: 1. Production of the host S. cerealella. Entomophaga, 26(4): 339-348.

6. Hassan, S. A. 1994. Improved method for the production of the Angoumois grain moth, S. cerealella. (Oliv.), pp.157-160. In E. Wajenberg (ed.),. "Trichogramma 
and other egg parasitoids" Proc. of $4^{\text {th }}$ International Symposium, Cairo, Egypt, 4-7 October 1994, Les Colloques de LoIINRA, 73:95-99.

7. Hoffman, M. P., D. L. Walker and A. M. Shelton. 1995. Biological of Trichogramma ostriniae (Hymenoptera) on Ostrinia nubilalis (Lep.: Pyralidae) and survey for additional host. Entomophaga, 40(314): 387-402.

8. Prenier, J. 1965. Les Trichogrammes parasites de proceias sacchaiphagus Boi. Borer de La canne a surere a Madagascar. Premier Partie: ecologie de Trichogramma australiicum Gir. Parasite autochtore effects du renforcement de la population parasite. Entomophaga, 10 (1): 83-96.

9. SAS Institute. 1988. SAS/STAT U⿴囗玉 sers Guide for personal computer: Statistics. SAS Institute Inc. Cary, NC.

10. Voegele, J., J. Daumal, P. H. Brun, and J. Onillon. 1975. Action du traitement au froid et aux ultiravioletes de L'ouef d' Ephestia kuehniella (Pyralidae) sur Le taux de multiplication de Trichogramma evanescens et T. brasiliensis (Hym., Trichogrammatidae). Entomophaga, 19(3): 341-348.

11. Zhang, Y., M. Cheng, W. Zhou, and C. Wang. 1991. Studies of the efficiency of rearing rice moth, Corcyra cephalonica (Lep.: Gelechiidae) with rice and wheat bran. Chinese J. Biocontrol, 7: 71-73. 
دراسات مقارنة على الخصائص البيولوجية لنوعى التريكوجراما ايفانسيز وتريكوجراما براسيكا نميت على بيض العو ائل البديلة

عرض للآثعة الفوق بنفسجية

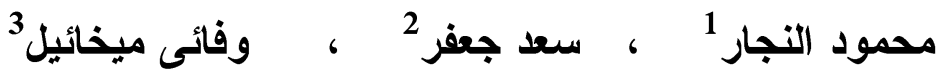

$$
\begin{aligned}
& \text { 1- - مركز البحوث الزراعية ، الجيزة ، مصر } \\
& \text { 2- الدعل المركزى للزراعة العضوية ، مركز البحوث الزرراعبة ، الجبزة ، مصر } \\
& \text { 3- قسم الدوارد الطبيعية ، معهة البحوث والدراسات الأفريقية ، جامعة القاهرة }
\end{aligned}
$$

*Corresponding author. Email: saad_bio_organic@yahoo.com

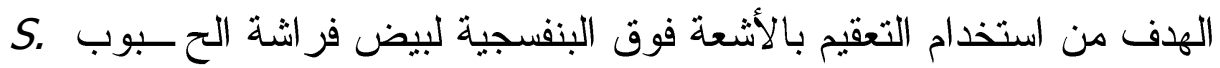
وفراشة دقيق البحر الأبيض المنوسط E. keuhniella هو تثبيط تطور النمو فئنة الجنينى داخل البيض حتى يكون مفضل لوسط التطفل لفتزة طويلة. يستخدم هذا النظام

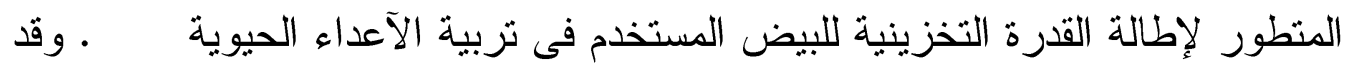

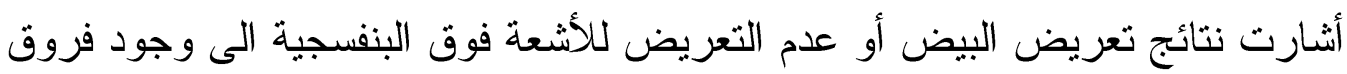
معنوية ما بين التربية على بيض فراشة الحبوب وفر اشة دقيق البحر الأبيض المتوسط وذلك على القدرة التتاسلية لنوعى التريكوجر اما محل الدراسة هما تريكوجر اما ايفانسيز

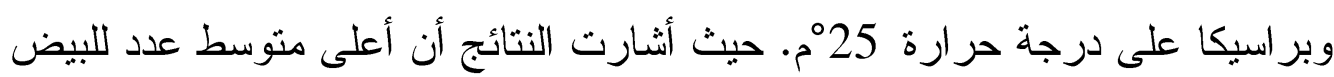

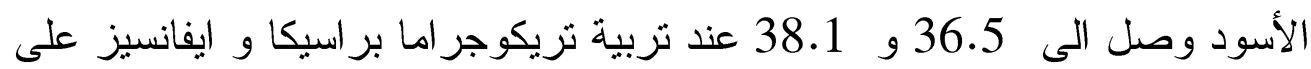

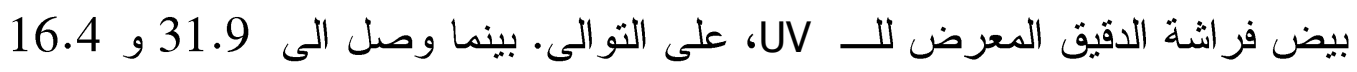

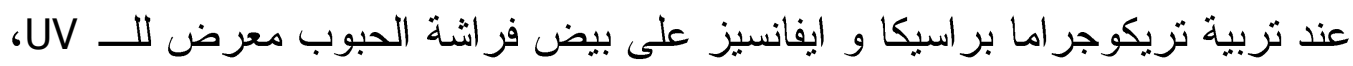

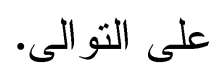

